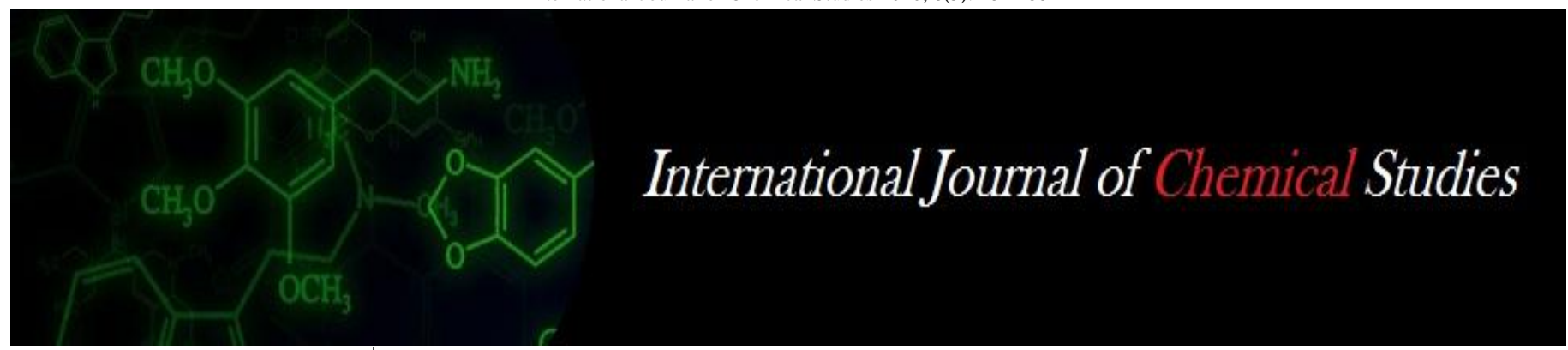

P-ISSN: 2349-8528

E-ISSN: 2321-4902

www.chemijournal.com

IJCS 2020; 8(5): 184-188

(C) 2020 IJCS

Received: 06-06-2020

Accepted: 16-08-2020

\section{Tariq A Bhat}

Division of Environmental

Sciences, SKUAST-Kashmir,

Shalimar, Srinagar, Jammu and

Kashmir, India

\section{JIA Bhat}

Division of Environmental

Sciences, SKUAST-Kashmir

Shalimar, Srinagar, Jammu and

Kashmir, India

\section{FA Lone}

Division of Environmental

Sciences, SKUAST-Kashmir,

Shalimar, Srinagar, Jammu and

Kashmir, India

\section{Tahir Ali}

Division of Soil Sciences,

SKUAST-Kashmir, Shalimar,

Srinagar, Jammu and Kashmir,

India

\section{Nageena Nazir}

Division of Agriculture

Statistics, SKUAST-Kashmir,

Shalimar, Srinagar, Jammu and

Kashmir, India

\section{Shabir H Khan}

Division of vegetable Science,

SKUAST-Kashmir, Shalimar,

Srinagar, Jammu and Kashmir,

India

\section{Shafat A Mir}

Division of Environmental

Sciences, SKUAST-Kashmir,

Shalimar, Srinagar, Jammu and

Kashmir, India

\section{Younus Wani}

College of Temperate Sericulture,

Mirgund, SKUAST-Kashmir,

Shalimar, Srinagar, Jammu and

Kashmir, India

\section{Corresponding Author:}

Tariq A Bhat

Division of Environmental

Sciences, SKUAST-Kashmir,

Shalimar, Srinagar, Jammu and

Kashmir, India

\section{Effect of vehicular pollution on physicochemical parameters and accumulation of heavy metals along roadside soils in Sonamarg forest ecosystem}

\author{
Tariq A Bhat, JIA Bhat, FA Lone, Tahir Ali, Nageena Nazir, Shabir H \\ Khan, Shafat A Mir and M Younus Wani
}

DOI: https://doi.org/10.22271/chemi.2020.v8.i5c.10295

\begin{abstract}
In an attempt to evaluate the effect of vehicular pollution on physicochemical parameters and accumulation of heavy metals on soil along roadside in Sonamarg forest ecosystem, soil samples from three different locations (Sonamarg, Baltal, Thajwas) comprising of disturbed and undisturbed sites were collected. The results indicated that the soils at all the study sites fall in the sandy loam class. Significant increase was recorded in soil $\mathrm{pH}$ and electrical conductivity in disturbed sites during both autumn and spring seasons. Moisture content was found higher at undisturbed sites in both the seasons and spring season recorded higher moisture content than the autumn season at all the locations and sites as well. Results showed that the heavy metals were of the ranges: $\mathrm{Pb}(0.173-1.283 \mathrm{ppm}), \mathrm{Zn}(1.215-4.045 \mathrm{ppm}), \mathrm{Ni}$ $(0.637-1.753 \mathrm{ppm}), \mathrm{Cu}(0.425-1.124 \mathrm{ppm})$ and $\mathrm{Cd}(0.037-0.093 \mathrm{ppm})$ respectively. Soil heavy metal concentration significantly decreased with increase in distance from the roadside. Autumn season showed higher depositions of heavy metals along the road than the spring season. Furthermore, the concentration of $\mathrm{Zn}$ was observed to be highest followed by $\mathrm{Ni}, \mathrm{Pb}, \mathrm{Cu}$ and $\mathrm{Cd}$ with mean values of 4.045, 1.753, $1.283,1.124$ and $0.093 \mathrm{ppm}$ respectively.
\end{abstract}

Keywords: Heavy metals, Pinus spp., Forest, Roadside

\section{Introduction}

Soil is a key part of the Earth system as it controls the hydrological, erosional, biological and geochemical cycles. The soil system also offers goods, services and resources to humankind (Berendse et al., 2015; Brevik et al., 2015; Decock et al., 2015; Smith et al., 2015) [4, 6, 7, 30]. Soil is a dynamic, natural body occurring on the surface of the earth which provides a place for plants, animals and microbial life and also a natural reservoir for metals. Its heavy metal concentration is associated with biogeochemical cycle, parent material, mineralogy, soil age, organic matter, particle size distribution, soil $\mathrm{pH}$, redox concentration, oxidation state and microbial activities (Ma et al., 1997; Lee et al., 2002; Ebong et al., 2007; Ololade et al., 2007) $[19,17,9,21]$. Soils have been used to detect the deposition, accumulation and distribution of heavy metals (Onder et al., 2007) ${ }^{[22]}$.

Pollution of the natural environment by heavy metals is a universal problem because these metals are indestructible and most of them have toxic effects on living organisms, when permissible concentration levels are exceeded (Mmolawa et al., 2011) ${ }^{[20]}$.

Road construction has been the main activity for development of industrial units. This has led to the loss of forest cover and subsequent loss of soil fertility.

Soils often show a high degree of contamination that can be attributed to motor vehicles. Various researchers have found that the concentrations of the metals lead, copper, zinc, cadmium and nickel decrease rapidly within 10 to $50 \mathrm{~m}$ from the roadsides (Pagotto et al., 2001; Joshi et al., 2010) ${ }^{[23,15] .}$

According to Panek and Zawodny (1993) ${ }^{[25]}$ pollution of roadside soils and plants by combustion of leaded petrol products is localized and usually limited to a belt of several metres wide on either side of the road. The high concentration of heavy metals along the roadside soils is due to high influx of motor vehicles (Pavlovic et al., 2016) ${ }^{[26]}$ which is considered as one of the major sources of heavy metal contamination (Devi et al., 2015; Jia et al., 2018) ${ }^{[8,14]}$. 
Over the last few years, the levels of heavy metals in the forest soil are increasing as a result of increasing environmental pollution from industrial, agricultural and vehicular emissions. Emissions of smoke from heavy traffic were reported to contain lead, cadmium, zinc and nickel which are present in fuel as anti-knock agents (Atayese et al., 2009) ${ }^{[2]}$. Vehicle exhausts emit these heavy metals such that soils, plants and even residents along roads with heavy traffic loads are subjected to increasing levels of contamination with heavy metals (Ghrefat and Yusuf, 2006) ${ }^{[12]}$.

In order to assess the accumulation and subsequent deterioration of soil health by heavy metals released from vehicular pollution, current investigation in roadside soils of Sonamarg forest was carried out.

\section{Material and methods \\ Study area}

The Jammu and Kashmir is the northern state of India situated between $32.15^{\circ}-37.05^{\circ} \mathrm{N}$ and $72.35^{\circ}-83.20^{\circ} \mathrm{E}$ with its summer capital Srinagar situated at an elevation of 5200 feet above sea level. The study was carried out in Sonamarg, which is located at $34.18^{\circ} \mathrm{N}$ and $75.15^{\circ} \mathrm{E}$ having an average elevation of 8989 feet lies about $79.4-\mathrm{km}$ from Srinagar (fig.1). It is very famous health resort in the state of Jammu and Kashmir. The route to Sonamarg passes through the dense forest having the dominant pine species of Pinus wallichaina (Jackson), Abies pindrow (Royle) and Cedrus deodara (Roxb.ex D. Don).

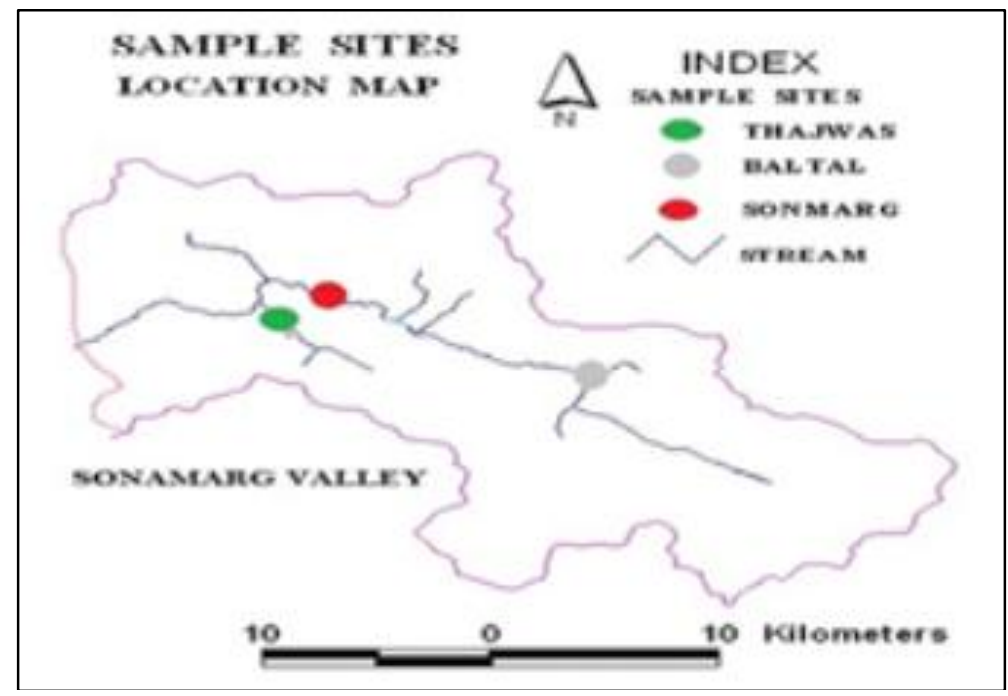

Fig 1: Map of study area showing position of sampling sites

\section{Soil Sampling}

Soil samples were taken from three different sampling sites viz., Baltal, Sonamarg and Thajwas with each location comprising of disturbed (up to $10 \mathrm{~m}$ from road) and undisturbed (about $150 \mathrm{~m}$ away from road) sites. Sampling was carried out in two different seasons, first in autumn (September, 2017) and second in spring (April, 2018). Soil samples were taken from soil layer $(0-30 \mathrm{~cm})$ within the rhizosphere of Pinus spp. at all the three sites after removing the leaf litter, debris etc.

The samples were transferred int polythene bags, labeled and taken to the laboratory for analysis. Samples for determining the moisture content were taken separately in sealed moisture boxes.

\section{Analysis of soil samples}

Soil samples collected were dried in shade and all clods and clumps were removed. Dried soil was sieved using $2 \mathrm{~mm}$ sieve to remove coarse particles before analysis. The following parameters were analyzed in the soil samples soil texture, soil $\mathrm{pH}$, soil electrical conductivity, soil moisture and heavy metals $(\mathrm{Pb}, \mathrm{Zn}, \mathrm{Ni}, \mathrm{Cu}$ and $\mathrm{Cd})$.

Texture of the soil was determined by hydrometric method (Bouyoucos, 1962) ${ }^{[5]}$. Soil $\mathrm{pH}$ and electrical conductivity was determined by potentiometric method with the help of $\mathrm{pH}$ meter and electrical conductivity meter (Jackson, 1973) ${ }^{[13]}$. Soil moisture was determined by gravimetric method (Prihar and Sandhu, 1968) ${ }^{[28]}$. In this method fresh soil samples were taken and sealed at the site of collection in moisture boxes. The soil was weighed in moisture boxes of known weight and then kept in oven at $105^{\circ} \mathrm{C}$. After two days, samples with zero per cent of moisture were weighed again. Moisture percentage was then determined by the following formula:

Moisture percentage $($ per cent $)=\frac{\text { Loss of weight }}{\text { Oven dry weight }} \times 100$

The presence of heavy metals was determined by Lindsay and Norwell's method (1978) ${ }^{[18]}$ using DTPA extraction method with the help of atomic absorbtion spectrophotometer (AAS). In this method $10 \mathrm{~g}$ of sieved soil sample and $20 \mathrm{ml}$ DTPA solution were taken in flasks and was shaken for two hours. After shaking the contents were filtered through Whatman's filter paper No. 42 and crystal clear filtrates were collected in glass tubes and these were analyzed for detection of heavy metals viz., $\mathrm{Pb}, \mathrm{Cu}, \mathrm{Ni}, \mathrm{Cd}$ and $\mathrm{Zn}$.

\section{Statistical analysis}

Statistical analysis was carried out by using Microsoft excel 2010 and online Opstat software.

\section{Results and discussion}

\section{Physicochemical properties}

The results on various physicochemical characteristics for the present study depicted diverse trends which are mentioned as: from the Table 1, The average clay, silt and sand contents of undisturbed sites were found in the order of 13.43, 34.23 and 52.33 per cent respectively. Similarly the average clay, silt and sand contents at the disturbed sites were found 11.43, 35.06 and 53.50 per cent, respectively. Using the USDA graph for the determination of soil textural classes, The soil under study area fall in the sandy loam class. 
Table 1: Particle size distribution of the soils of the experimental site

\begin{tabular}{|c|c|c|c|c|}
\hline Site & $\begin{array}{c}\text { Clay } \\
\text { (per cent) }\end{array}$ & $\begin{array}{c}\text { Silt } \\
\text { (per cent) }\end{array}$ & $\begin{array}{c}\text { Sand } \\
\text { (per cent) }\end{array}$ & Type \\
\hline Baltal disturbed & 12.2 & 39.1 & 48.7 & \multirow{6}{*}{$\begin{array}{l}\text { Sandy } \\
\text { loam }\end{array}$} \\
\hline Baltal undisturbed & 13.7 & 35.9 & 50.4 & \\
\hline Sonamarg disturbed & 10.7 & 33.6 & 55.7 & \\
\hline Sonamarg undisturbed & 13.3 & 34.6 & 52.1 & \\
\hline Thajwas disturbed & 11.4 & 32.5 & 56.1 & \\
\hline Thajwas undisturbed & 13.3 & 32.2 & 54.5 & \\
\hline
\end{tabular}

As depicted in Table 2, high soil $\mathrm{pH}$ (6.96) was found at disturbed site of Sonamarg while the lowest $\mathrm{pH}$ was found at undisturbed site of Thajwas with a value of (5.92) in autumn season. During spring season, the highest average soil $\mathrm{pH}$ (6.64) was found to be at disturbed site of Sonamarg and the lowest $\mathrm{pH}$ (5.33) was found at undisturbed site of Thajwas. Similarly, the highest soil electrical conductivity $\left(0.83 \mathrm{ds} \mathrm{m}^{-1}\right)$ was found at disturbed site of Sonamarg with lower value $\left(0.56 \mathrm{ds} \mathrm{m}^{-1}\right)$ at undisturbed site of Thaj was in autumn season. During spring season the highest soil electrical conductivity $\left(0.52 \mathrm{ds} \mathrm{m}^{-1}\right)$ was found at disturbed site of Sonamarg while the lowest value of electrical conductivity $\left(0.21 \mathrm{ds} \mathrm{m}^{-1}\right)$ was found at undisturbed site of Thaj was. The high moisture content (23.73 per cent) was found at undisturbed site of Thaj was while as disturbed site of Sonamarg showed lower moisture content (13.90 per cent) during autumn season. In spring season higher moisture content (27.09 per cent) was found at undisturbed site of Thaj was with lower value (16.22 per cent) at disturbed site of Sonamarg. The data revealed that the moisture content was significantly higher in undisturbed soils than in the disturbed soils.

\section{Heavy metal content in soil}

Results showed that heavy metal concentrations in soil decreased with increase in distance from the road.

From the Table 3, The results revealed that autumn season recorded the highest average values of lead (1.283 ppm), zinc (4.045 ppm), copper (1.124 ppm) and cadmium (0.093 ppm) respectively at disturbed site of Sonamarg whereas highest nickel content $(1.753 \mathrm{ppm})$ was found at disturbed area of Thaj was. The lowest average values of lead $(0.213 \mathrm{ppm})$, zinc (1.533 ppm), copper (0.443 ppm), cadmium (0.043 ppm) were found at undisturbed site of Thaj was whereas lowest nickel content $(0.743 \mathrm{ppm})$ was found at undisturbed site of Sonamarg. During spring season, the highest average values of lead (0.885 ppm), zinc (3.893 ppm), copper (1.053 ppm), cadmium $(0.084 \mathrm{ppm})$ were found at disturbed site of Sonamarg with lower values of lead $(0.173 \mathrm{ppm})$, zinc (1.215 ppm), copper $(0.45 \mathrm{ppm})$, cadmium $(0.037 \mathrm{ppm})$ at the undisturbed site of Thaj was Whereas the highest nickel content $(1.747 \mathrm{ppm})$ was found at disturbed site of Thaj was with lower value $(0.637 \mathrm{ppm})$ at undisturbed site of Sonamarg. The concentration of $\mathrm{Zn}, \mathrm{Ni}, \mathrm{Pb}$ was found higher at disturbed sites as compared to the undisturbed sites at all locations in both seasons.

\section{Discussion}

Decrease in vegetation cover in forest had left soil naked, thus resulting in sandy loam textural class. Similar findings were reported by Faruqi et al. (2013) [10]; Singh et al. (2018) [31]. Generally the forest soil is characterized by slightly acidic to neutral $\mathrm{pH}$ in nature. Higher $\mathrm{pH}$ and electrical conductivity was observed in disturbed sites as compared to undisturbed ones. Significant increase was recorded in soil $\mathrm{pH}$ and electrical conductivity in disturbed area during both autumn and spring seasons. Increase in $\mathrm{pH}$ in deforested area is attributed to decrease in organic matter accumulation which directly depends upon the forest cover. The increase in $\mathrm{pH}$ can also be attributed to decrease in accumulation and subsequent slow decomposition of organic matter, which releases acids (de Hann, 1977). Higher $\mathrm{pH}$ and electrical conductivity near to the highway and lower away from highway could be due to decline of forest flora. These results were found in concordance with results of Grigalaviciene et al. (2005); Joshi et al. (2010) ${ }^{[15]}$; Das and Dkhar (2011) and Shah and Jeelani (2015); Singh et al. (2018) [31]. Higher moisture content was found in spring season as compared to the autumn season which may be attributed to high rate of precipitation in spring than autumn. The roadside disturbed forest soil contained less moisture due to higher evapotranspiration losses of its exposed land resulted by the loss of forest cover. The results obtained were in concordance with results observed by Joshi et al. (2010) ${ }^{[15]}$; Faruqi et al. (2013) ${ }^{[10]}$ and Shah and Jeelani (2015).

\section{Heavy metals in soil}

The soil environment is an important sink for heavy metals. The content of heavy metals $(\mathrm{Pb}, \mathrm{Cu}, \mathrm{Zn}, \mathrm{Ni}$ and $\mathrm{Cd}$ ) was observed higher in disturbed area as compared to the undisturbed area at all the sites in both the seasons. It was observed from (Table 3) that autumn season showed higher accumulation of heavy metals than spring.

The increased content of heavy metals accumulation may be due to increase in traffic movements, which results in high rate of exhausts, wear and tear of motor vehicle tyres and other vehicle services could have added high degree of heavy metal contaminations to the roadside soil (Paggotto et al., 2001). Weckwerth (2001) [33]; Ramakrishnaiah and Somashekar 2003) ${ }^{[29]}$ reported that roadside soil contains high percentage of heavy metal contamination. Kord et al. (2010) ${ }^{[16]}$ also reported that the highest and the lowest metal content were found in the heavy traffic zone and low traffic zone respectively. Wang et al. (1996) ${ }^{[32]}$ also revealed that all roadside soils contained higher lead levels than soil near to little motor traffic or no traffic sides. Remarkable high levels of heavy metals were found in the nearest point to high-way (Garcia and Millan, 1994) ${ }^{[11]}$. Heavy metals (Pb, Zn, Cu and Cd) showed an increasing trend in their content with increased urbanization and transportation (Aksoy and Ozturk, 1996) ${ }^{[3]}$

These results were in agreement with findings of Aksoy and Ozturk (1996) ${ }^{[3]}$; Paggotto et al. (2001); Wreckwerth (2001); Petrova et al. (2014) ${ }^{[27]}$; Panda and Dhal (2015) ${ }^{[24]}$; Singh et al. $(2018)^{[31]}$.

During the study, the positive correlation was observed between $\mathrm{pH}$ and the concentration of heavy metals in the soils (table 4). A similar finding was reported by Agnieszka et al. $(2014)^{[1]}$. 
Table 2: Effect of vehicular pollution on physicochemical properties in pine forest soil along Sonamarg Highway in autumn and spring seasons.

\begin{tabular}{|c|c|c|c|c|c|}
\hline \multirow{7}{*}{ Autumn season } & Location & Site & pH & $\begin{array}{c}\text { EC } \\
(\mathrm{ds} / \mathrm{m})\end{array}$ & Moisture content (\%) \\
\hline & \multirow{2}{*}{ Sonamarg } & Disturbed & $6.968 \pm 0.033$ & $0.830 \pm 0.031$ & $13.90 \pm 0.031$ \\
\hline & & Undisturbed & $6.688 \pm 0.034$ & $0.731 \pm 0.031$ & $19.14 \pm 0.031$ \\
\hline & \multirow{2}{*}{ Baltal } & Disturbed & $6.756 \pm 0.049$ & $0.741 \pm 0.031$ & $15.77 \pm 0.031$ \\
\hline & & Undisturbed & $6.384 \pm 0.033$ & $0.630 \pm 0.031$ & $20.50 \pm 0.031$ \\
\hline & \multirow{2}{*}{ Thajwas } & Disturbed & $6.530 \pm 0.031$ & $0.681 \pm 0.031$ & $18.30 \pm 0.039$ \\
\hline & & Undisturbed & $5.928 \pm 0.028$ & $0.560 \pm 0.031$ & $23.73 \pm 0.044$ \\
\hline \multirow{6}{*}{ Spring season } & \multirow{2}{*}{ Sonamarg } & Disturbed & $6.640 \pm 0.038$ & $0.520 \pm 0.031$ & $16.22 \pm 0.031$ \\
\hline & & Undisturbed & $5.664 \pm 0.030$ & $0.410 \pm 0.031$ & $21.44 \pm 0.032$ \\
\hline & \multirow{2}{*}{ Baltal } & Disturbed & $6.414 \pm 0.036$ & $0.391 \pm 0.031$ & $20.72 \pm 0.028$ \\
\hline & & Undisturbed & $5.736 \pm 0.036$ & $0.281 \pm 0.031$ & $23.93 \pm 0.034$ \\
\hline & \multirow{2}{*}{ Thajwas } & Disturbed & $6.340 \pm 0.041$ & $0.320 \pm 0.031$ & $24.53 \pm 0.039$ \\
\hline & & Undisturbed & $5.338 \pm 0.034$ & $0.211 \pm 0.031$ & $27.09 \pm 0.036$ \\
\hline
\end{tabular}

Table 3: Effect of vehicular pollution on heavy metal content (ppm) in pine forest soil along Sonamarg Highway in autumn and spring seasons.

\begin{tabular}{|c|c|c|c|c|c|c|c|}
\hline \multirow{7}{*}{ Autumn season } & location & Site & Pd & $\mathrm{Cu}$ & $\mathbf{N i}$ & Cd & $\mathbf{Z n}$ \\
\hline & \multirow{2}{*}{ Sonamarg } & Disturbed & $1.283 \pm 0.003$ & $1.124 \pm 0.003$ & $1.042 \pm 0.0036$ & $0.093 \pm 0.003$ & $4.045 \pm 0.003$ \\
\hline & & Undisturbed & $0.511 \pm 0.003$ & $0.913 \pm 0.003$ & $0.743 \pm 0.003$ & $0.079 \pm 0.003$ & $2.606 \pm 0.002$ \\
\hline & \multirow{2}{*}{ Baltal } & Disturbed & $0.903 \pm 0.449$ & $0.843 \pm 0.003$ & $1.684 \pm 0.003$ & $0.073 \pm 0.003$ & $3.924 \pm 0.003$ \\
\hline & & Undisturbed & $0.413 \pm 0.003$ & $0.634 \pm 0.003$ & $0.933 \pm 0.003$ & $0.064 \pm 0.003$ & $2.316 \pm 0.003$ \\
\hline & \multirow{2}{*}{ Thajwas } & Disturbed & $0.814 \pm 0.003$ & $0.757 \pm 0.004$ & $1.753 \pm 0.003$ & $0.058 \pm 0.003$ & $2.432 \pm 0.003$ \\
\hline & & Undisturbed & $0.213 \pm 0.003$ & $0.443 \pm 0.003$ & $1.547 \pm 0.0034$ & $0.043 \pm 0.003$ & $1.533 \pm 0.002$ \\
\hline \multirow{6}{*}{ Spring season } & \multirow{2}{*}{ Sonamarg } & Disturbed & $0.885 \pm 0.004$ & $1.053 \pm 0.003$ & $1.016 \pm 0.003$ & $0.084 \pm 0.003$ & $3.893 \pm 0.003$ \\
\hline & & Undisturbed & $0.497 \pm 0.003$ & $0.745 \pm 0.004$ & $0.637 \pm 0.003$ & $0.068 \pm 0.003$ & $2.106 \pm 0.002$ \\
\hline & \multirow{2}{*}{ Baltal } & Disturbed & $0.791 \pm 0.003$ & $0.824 \pm 0.003$ & $1.584 \pm 0.003$ & $0.065 \pm 0.003$ & $3.414 \pm 0.003$ \\
\hline & & Undisturbed & $0.384 \pm 0.003$ & $0.616 \pm 0.002$ & $0.743 \pm 0.003$ & $0.051 \pm 0.003$ & $1.986 \pm 0.003$ \\
\hline & \multirow{2}{*}{ Thajwas } & Disturbed & $0.394 \pm 0.003$ & $0.734 \pm 0.003$ & $1.747 \pm 0.003$ & $0.041 \pm 0.003$ & $2.014 \pm 0.002$ \\
\hline & & Undisturbed & $0.173 \pm 0.003$ & $0.425 \pm 0.003$ & $1.487 \pm 0.003$ & $0.037 \pm 0.003$ & $1.215 \pm 0.003$ \\
\hline
\end{tabular}

Table 4: Correlation coefficient between soil properties and heavy metals along Sonamarg highway

\begin{tabular}{|c|c|c|c|c|c|c|c|}
\hline & pH & EC & SM & $\mathbf{P b}$ & Zn & $\mathbf{N i}$ & $\mathbf{C u}$ \\
\hline EC & 0.393 & & & & & & \\
\hline SM & $-0.817 * *$ & -0.508 & & & & & \\
\hline $\mathrm{Pb}$ & $0.782 * *$ & 0.211 & $-0.916 * *$ & & & & \\
\hline $\mathrm{Zn}$ & $0.805 * *$ & 0.191 & $-0.905 * *$ & $0.922 * *$ & & & \\
\hline $\mathrm{Ni}$ & 0.166 & -0.360 & 0.116 & 0.034 & -0.016 & & \\
\hline $\mathrm{Cu}$ & $0.773 * *$ & 0.211 & $-0.865 * *$ & $0.880 * *$ & $0.887 * *$ & -0.227 & \\
\hline $\mathrm{Cd}$ & $0.672 * *$ & 0.506 & $-0.910 * *$ & $0.817 * *$ & $0.854 * *$ & 0.445 & $0.902 * *$ \\
\hline
\end{tabular}

\section{Conclusion}

Physicochemical properties and levels of heavy metals in roadside soils of some selected locations along roadside were determined in this study. Heavy metal concentrations in roadside soil samples are mostly higher than those in the soil of undisturbed area due to metals emitted from vehicle exhausts which in turn leads to changes in the physicochemical properties of the soil. Higher content of heavy metals along roadside indicates vehicular pollution alarm at Sonamarg tourist resort thus needs to be tackled scientifically. Proper biomonitoring of the environment should be done as often as possible so as to enlighten the public on the dangers of heavy metal pollution.

Conflict of interest: There is no conflict of interest among the authors.

Acknowledgement: First Author is highly thankful to the Division of Environmental Sciences, SKUAST-Kashmir, Shalimar, Srinagar for providing the laboratory facilities during the study period of this research work.

\section{References}

1. Agnieszka B, Tomasz, C, Jerzy W. Chemical properties and toxicity of soils contaminated by mining activity. Ecotoxicology. 2014; 23:1234-1244.

2. Atayese MO, Eigbadon AI, Oluwa KA, Adesodun JK. Heavy metal contamination of amaranthus grown along major highways in Lagos. African Crop Science Journal. 2009; 16(4):225-229.

3. Aksoy A, Ozturk M. Phoenix dactylifera as a biomonitors of heavy metal pollution in Turkey. Journal of Trace and Microprobe Technique. 1996; 14:605-614.

4. Berendse F, Van RJ, Jongejans E, Keesstra S. Loss of plant species diversity reduces soil erosion resistance. Ecosystems. 2015; 18(5):881-888.

5. Bouyoucos CJ. Hydrometer method improved for making particle analysis of soil. Agronomy Journal. 1962; 54(5):464-465.

6. Brevik EC, Cerdà A, Mataix-Solera J, Pereg L, Quinton JN, Six J et al. The interdisciplinary nature of soil. Soil. 2015; 1(1):117-118.

7. Decock C, Lee J, Necpalova M, Pereira EIP, Tendall DM, Six $\mathrm{J}$ et al. Mitigating $\mathrm{N}_{2} \mathrm{O}$ emissions from soil: from patching leaks to transformative action, Soil. 2015; 1(2):687-689.

8. Devi U, Hoque RR, Sarma KP. Accumulation of trace metals in soil and trees by the highway passing through an ecological heritage area Department of Environmental Science, Tezpur University, Assam (India). Journal of Environmental Research and Development. 2015; 9:3-7.

9. Ebong GA, Etuk HS, Johnson AS. Heavy metal accumulation by Talinum. Journal of Applied Science. 2007; 7(10):1404-1409.

10. Faruqi RA, Bhat JIA, Farooq S, Shamsul H, Khan OA. Heavy metal deposition and physico-chemical changes in pine forest soil of Gulmarg as influenced by vehicular 
pollution. International Journal of Recent Scientific Research. 2013; 4(6):891-894.

11. Garcia R, Millan E. Assessment of $\mathrm{Cd}, \mathrm{Pb}$ and $\mathrm{Zn}$ contamination in road side soil and grasses from Gipuzkoa (Spain). Chemosphere. 1994; 37(8):1615-1625.

12. Ghrefat $\mathrm{H}$, Yusuf N. Assessing $\mathrm{Mn}, \mathrm{Fe}, \mathrm{Cu}, \mathrm{Zn}$ and $\mathrm{Cd}$ pollution in bottom sediments of Wadi Al-Arab Dam, jordan. Chemosphere. 2006; 65(11):2114-2121.

13. Jackson ML. Soil chemical analysis, Prentice Hall of India, Private Limited, New Delhi, 1973.

14. Jia Z, Li S, Wang L. Assessment of soil heavy metals for eco-environment and human health in a rapidly urbanization area of the upper Yangtze Basin. Scientific Reports. 2018; 8:3256.

15. Joshi SR, Kumar R, Bhagobaty RK, Thokchom S. Impact of pollution on microbial activities in sub-tropical forest soil of north east India. Research. Journal of Environmental Sciences. 2010; 4(3):280-287.

16. Kord B, Mataji A, Babaie S. Pine (Pinus eldarica) needles as indicator for heavy metals pollution. International Journal of Environmental Science and Technology. 2010; 7:79-84.

17. Lee I, Kim OK, Chang Y, Bae B, Kim HH, Baek KH et al. Heavy metal concentrations and enzymatic activities in soil from contaminated Korean shooting range. Journal of Bioscience and Bioengineering. 2002; 94(5):406-411.

18. Lindsay WL, Norvell WA. Development of a DTPA-Soil test for $\mathrm{Zn}, \mathrm{Fe}, \mathrm{Mn}$ and $\mathrm{Cu}$. Soil Science Society of America Journal. 1978; 42(3):421-428.

19. Ma LQ, Tam F, Harris WG. Concentrations and distributions of eleven metals in Florida soils. Journal of Environment Quality. 1997; 26(3):769-775.

20. Mmolawa KB, Likuku AS, Gaboutloeloe GK. Assessment of heavy metal pollution in soils along major roadside areas in Botswana. African Journal of Environmental Science and Technology. 2011; 5(3):186196.

21. Ololade IA, Ashoghon AO, Adeyemi O. Plant's level of chromium and nickel at a refuse site. Any positive impact. Journal of Applied Science. 2007; 7(13):17681773.

22. Onder S, Dursun S, Gezgin S, Demirbas A. Determination of metal pollution in grass and soil of city centre green areas (Konya, Turkey). Polish Journal of Environmental Studies. 2007; 16:1.

23. Pagotto C, Remy N, Cloirec P. Heavy metal pollution of road dust and roadside soil near a major rural highway. Environmental Technology. 2001; 22(3):307-319.

24. Panda SS, Dhal NK. Assessment of heavy metal contamination of soils and plants in and around open cast mines of Sukinda, India. Asian Journal of Environmental Science. 2015; 10:76-82.

25. Panek E, Zawodny Z. Trace metals in the roadside mountain soils of Sierra Nevada, Spain. Environment Geochemistry and Health. 1993; 15(4):229-235.

26. Pavlovic P, Mitrović M, Đorđević D, Sakan J, Slobodnik I, Liška B et al. Assessment of the contamination of riparian soil and vegetation by trace metals - a Danube River case study. Science of the Total Environment. 2016; 540:396-409.

27. Petrova S, Yurukova L, Velcheva I. Possibilities of using deciduous tree species in trace element biomonitoring in an urban area. Atmospheric Pollution Research. 2014; 5:196-202.
28. Prihar SS, Sandhu BS. A rapid method for soil moisture determination. Soil Science. 1968; 105(3):142-144.

29. Ramakrishnaiah H, Somashekar RK. Heavy metal contamination in roadside soil and their mobility in relation to $\mathrm{pH}$ and organic carbon. Soil and sediment contamination. 2003; 11(5):643-654.

30. Smith P, Cotrufo MF, Rumpel C, Paustian K, Kuikman PJ, Elliott JA et al. Verification of traffic emitted aerosol components in the ambient air of Cologne (Germany). Atmospheric Environment. 2001; 35(32):5525-5536.

31. Singh DV, Bhat JIA, Bhat RA, Dervash MA. Ganei S. A. 2018. Vehicular stress a cause for heavy metal accumulation and change in physico-chemical characteristics of road side soils in Pahalgam. Environmental Monitoring Assessment. 2001; 190:353.

32. Wang YF, Huang KL, Li CT, Mi HH, Luo JH, Tsai PJ et al. Emission of fuel metals content from a diesel vehicle engine. Atmospheric Environment. 1996; 33:4637-4643.

33. Weckwerth G. Verification of traffic emitted aerosol components in the ambient air of Cologne (Germany). Atmospheric Environment. 2001; 35(32):5525-5536. 